\title{
The new data on distribution of the pygmy grasshopper Tetrix tartara s.l. (Orthoptera: Tetrigoidea: Tetrigidae) and its vibrational signals
}

\author{
Новые данные о распространении прыгунчика Tetrix tartara s.l. \\ (Orthoptera: Tetrigoidea: Tetrigidae) и его вибросигналы
}

\author{
A.A. Benediktov \\ А.А. Бенедиктов
}

\begin{abstract}
Moscow State University, Biology Faculty, Department of entomology, Moscow 119991, Russia. E-mail: entomology@yandex.ru Московский государственный университет, Биологический факультет, кафедра энтомологии, Москва 119991, Россия.
\end{abstract}

KEY WORDS: Orthoptera, Tetrigoidea, Tetrigidae, Tetrix tartara tartara, Tetrix tartara subacuta, Russia, vibrational signals.

КЛЮЧЕВЫЕ СЛОВА: Orthoptera, Tetrigoidea, Tetrigidae, Tetrix tartara tartara, Tetrix tartara subacuta, Россия, вибросигналы.

ABSTRACT. This is a review of distribution of the polytypical taxon pygmy grasshopper Tetrix tartara (I.Bol.). Northern subspecies T. tartara subacuta B.Bienko is found on the European part of the Russia and Western Kazakhstan for the first time. This is the westernmost point of this taxon habitat. Vibrational signals of T. tartara tartara from Kyrgyzstan describe, oscillogramms are given

РЕЗЮМЕ. Рассмотрено распространение прыгунчика Tetrix tartara (I.Bol.). Северный подвид T. tartara subacuta B.-Bienko впервые найден на территории Европейской части России и Западного Казахстана. Это самая западная точка обнаружения таксона. Описаны вибрационные сигналы T. tartara tartara из Киргизии, осциллограммы приводятся.

\section{Introduction}

Tetrix tartara (I.Bolivar, 1887) — is polytypical taxon with two subspecies which differ only by height median carina and its anterior margin of pronotum in dorsal view near medium carina.

The geographical area of the southern nominative subspecies T. tartara tartara (I.Bolivar, 1887) includes territories of Turkmenistan, Afghanistan, Tajikistan, Southern and Central Kyrgyzstan [Podgornaja, 1983; Storozhenko et al., 1994]. This subspecies also has been recently recorded in Iran [Lehr et al., 2007] and Central Uzbekistan [Benediktov, 2010] (Fig. 1, point 1).

The distribution of the northern subspecies T. tartara subacuta Bey-Bienko, 1951 includes Central and South-Eastern Kazakhstan, Northern Kyrgyzstan, Mon- golia, China (Inner Mongolia). Also this taxon was found in Asian part of Russia in Russian Altai [Sergeev, 1982; Storozhenko et al., 1994] (Fig. 1, point 9). This subspecies has been recently specified in Northern Uzbekistan (Karakalpakstan) [Childebayev et al., 2011]. But in 2010 T. tartara subacuta for the first time was collected in European part: Astrakhan region of Russia and Western Kazakhstan (Fig. 1, points 78). This is the westernmost points for a habitat.

This paper is result of the Tetrigidae collection investigation in Department of entomology of Biology Faculty of Moscow State University.

Materials and methods

Vibrations are recorded by a minidisk-recorder Sony MD Walkman MZ-RH910 (20-20000 Hz) with piezoelectric adapter $(30-12000 \mathrm{~Hz})$, the head of the adapter contacted with cardboard plates $75 * 90 \mathrm{~mm}$, slightly springing. Insects were placed on the cardboard. Temperature during recording $+27 \ldots+30^{\circ} \mathrm{C}$.

The following terminology was used: series - a sequence of pulses, separated from other similar series with long pauses; pulses - elementary parcels, characterized by fast growing and rapidly decreasing amplitude.

\section{Description}

Tetrix tartara tartara (I.Bolivar, 1887)

MATERIAL (all specimens f. brachyptera). UZBEKISTAN: Nuratau, 4.VIII.2000, 2 우 (A.Kashirsky) (Fig. 1, point 1); TAJIKISTAN: Leninabadskaja obl., Lajliak, 20.VII.1959, $20^{7} \sigma^{7}$ and 2 q (A.Rasnitsyn) (Fig. 1, point 2); Khatlon prov., Farkhor district, Novobod, $37.551^{\circ} \mathrm{N}, 69.460^{\circ} \mathrm{E}, 457$ asl, 6.VI.2010, 2 ㅇ (K.Tomkovich) (Fig. 1, point 3); KYRGYZSTAN: Sary- 


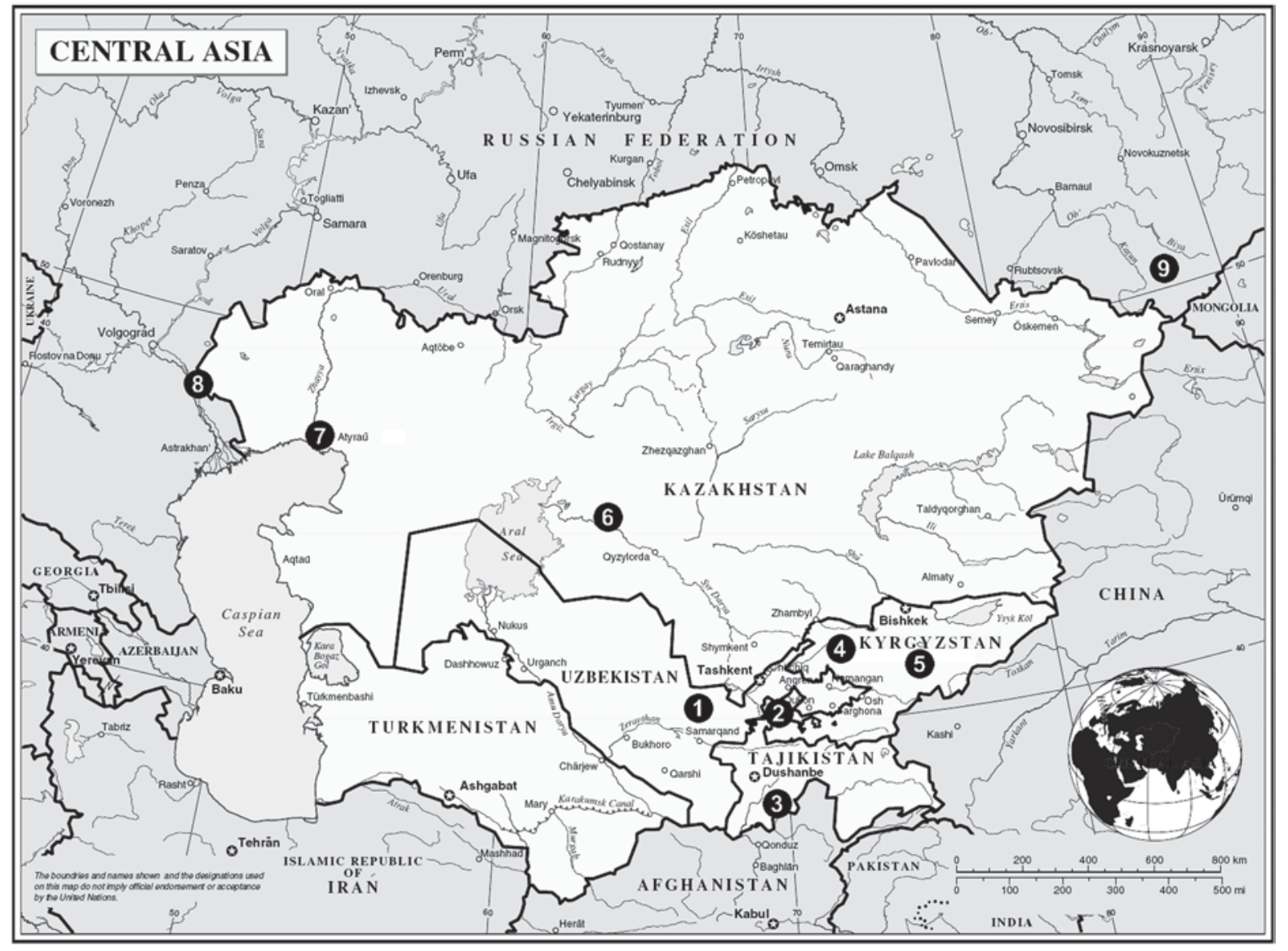

Fig. 1. The finding of Tetrix tartara ssp. from Asia and Europe. Points 1-8 - look in the text; 9 - Kuraiskaia kotlovina [Sergeev, 1982; Storozhenko et al., 1994].

Рис. 1. Находки Tetrix tartara ssp. в Азии и Европе. Точки 1-8 - см. в тексте; 9 - Курайская котловина [Сергеев, 1982; Storozhenko et al., 1994].

Chelek res., Arkit, 1600 asl, 15.VII.1999, $20^{7} 0^{7}$ and 390 (V.Gromenko) (Fig. 1, point 4); left tributary Naryn riv., $10 \mathrm{~km}$ NE Koshtebe, 1700 asl, 18.VI.2004, $20^{7} \sigma^{7}$ and + (V.Gromenko) (Fig. 1, point 5).

GENERAL DISTRIBUTION. Iran, Turkmenistan, Afghanistan, Central Uzbekistan, Tajikistan, Southern and Central Kyrgyzstan.

NOTE. Kyrgyz specimens from Arkit (Fig. 1, point 4) and Koshtebe (Fig. 1, point 5) is closely related to the specimens ssp. subacuta from Kazakhstan (Fig. 1, points 6), however differ in higher median carina and more long and sharp angle anterior margin of pronotum in dorsal view near medium carina. These exemplars have intermediate morphological characters between two subspecies. Their (as "Tetrix tartara" without established subspecies) vibrational signals were briefly described before [Benediktov, 2005].

VIBRATIONAL SIGNALS. Series of rivalry signals include $10-13$ pulses with repetition period of pulses $55-85 \mathrm{~ms}$ (Figs 2-10). Duration of series is $750-1140 \mathrm{~ms}$, and their repetition periods $1.9-2.2 \mathrm{~s}$.

Sometimes males emit discrete pulses between series (Fig. 11).

Before copulation male jump on the female and produce long signal. This signal consists of many short pulses with repetition periods $130-200 \mathrm{~ms}$ (Fig. 12).
Tetrix tartara subacuta Bey-Bienko, 1951

MATERIAL. KAZAKHSTAN: Kazaly distr., Basykara env., near r. Syr Darya, $45.755^{\circ} \mathrm{N}, 62.303^{\circ} \mathrm{E}, 67 \mathrm{~m}$ asl, YPT, $15-19$. V.2011, $20^{7} O^{7}$ and + f. macroptera, $40^{7} O^{7}$ f. brachyptera, larva $\mathrm{O}^{7}$ (K.Tomkovich) (Fig. 1, point 6); Atyrau env., vill. Damba-Akzhajyk Reserve, $46.95^{\circ} \mathrm{N}, 51.727^{\circ} \mathrm{E}$, riv. Ural bank, YPT, $22 \mathrm{~V} 2011,3 \mathrm{O}^{7} \mathrm{O}^{7}$ and $q$ f. brachyptera, larva + (K.Tomkovich) (Fig. 1, point 7); RUSSIA: Astrakhan reg., Baskunchak salt-like, $48.193^{\circ} \mathrm{N}, 46.813^{\circ} \mathrm{E}$, semidesert, 1-2.V.2010, O f. macroptera (K. Tomkovich) (Fig. 1, point 8).

GENERAL DISTRIBUTION. Kazakhstan, Northern Kyrgyzstan, Northern Uzbekistan, Mongolia, China (Inner Mongolia); Russia (Astrakhan region and Russian Altai).

NOTE. Tetrix tenuicornis (J.Sahlberg, 1893) (OT f. brachyptera) and T. subulata (Linnaeus, 1758) (4 $\sigma^{7} \sigma^{7}$ f. macroptera) was found with T. tartara subacuta (Figs 13-14) by K. Tomkovich in Baskunchak. Detection of T. tartara subacuta in Russia and Western Kazakhstan is very interesting. The discovery of this species near Baskunchak salt-lake could indicate either weak knowledge of the fauna of this region, or possible settlement process of this species to west from Kazakhstan, as evidenced by the well-developed wings forma macroptera.

ACKNOWELEDCEMENTS. I sincerely grateful to K.P. Tomkovich and V.A. Gromenko (both from Moscow) for the collection of this interesting insects. 


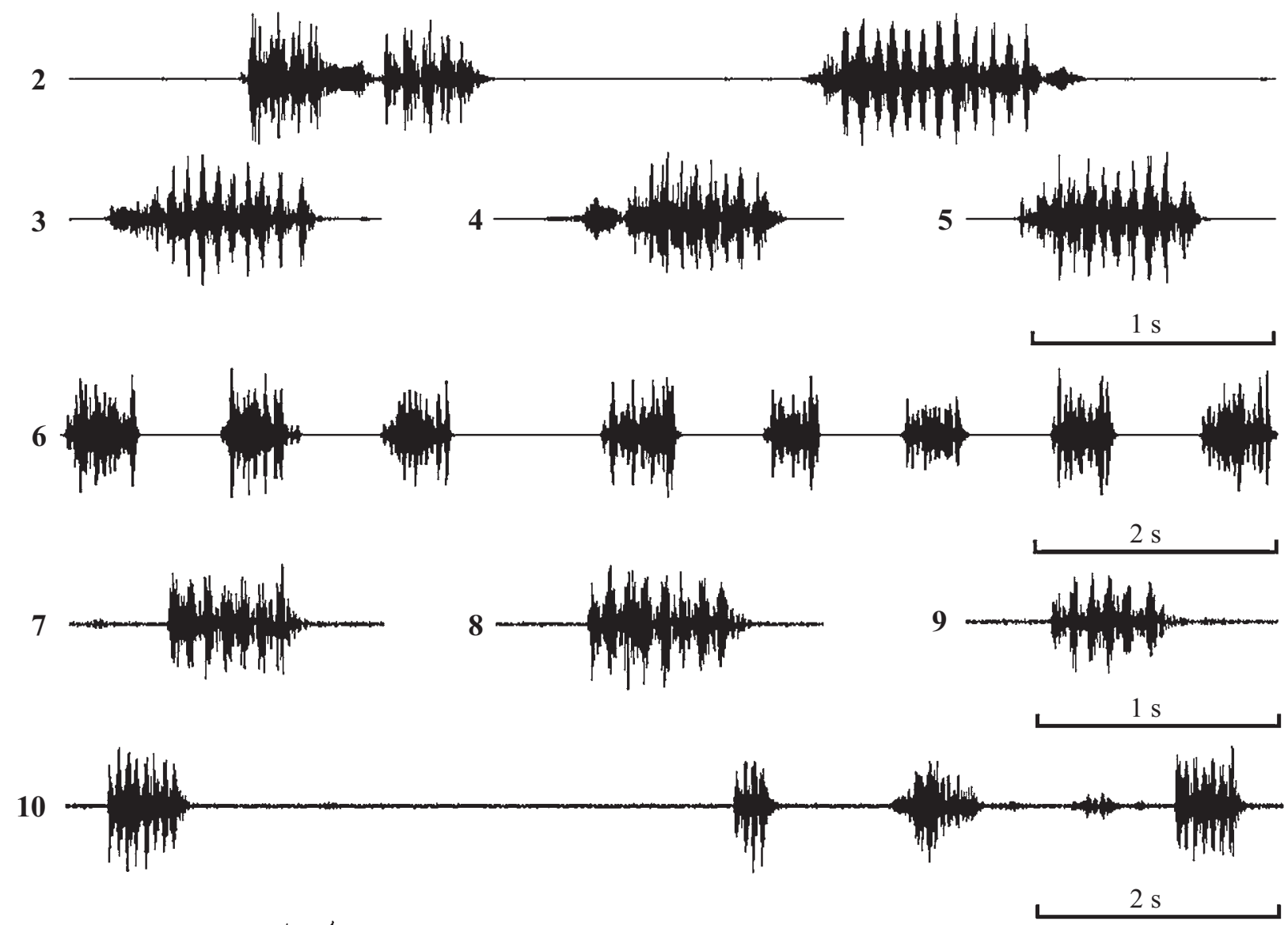

11

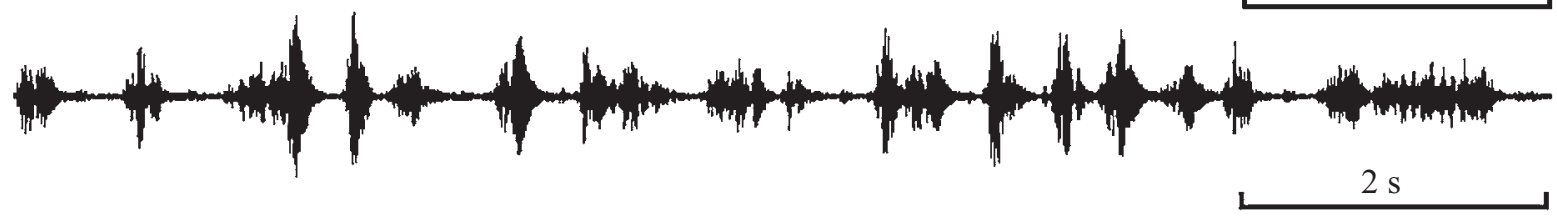

12

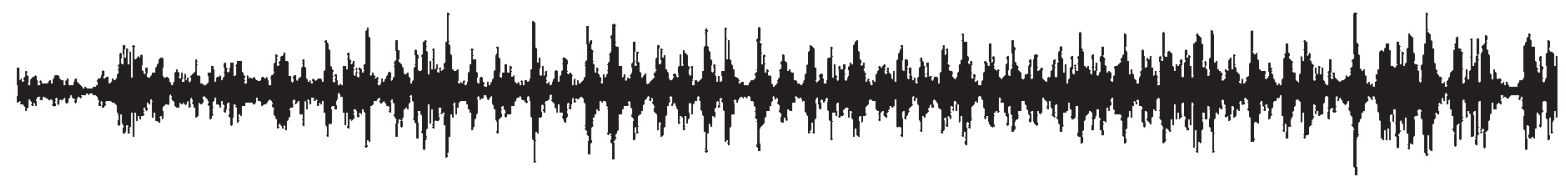

Figs 2-12. Oscillogramms of the vibrational signals of Tetrix tartara tartara males from Kyrgyzstan: Arkit (2-5) and Koshtebe (6-12): $2-10$ - series of rivalry; 11 - pulses of rivalry; 12 - male and female before copulation.

Рис. 2-12. Осциллограммы вибрационных сигналов самцов Tetrix tartara tartara из Киргизии: Аркит (2-5) и Коштебе (6-12). 210 - перекличка самцов сериями; 11 - перекличка самцов пульсами и сериями; 12 - самец и самка перед копуляцией.

\section{References}

Benediktov A.A. 2005. [Vibratory signals in the family Tetrigidae (Orthoptera)]// Trudy Russkogo Entomol. Obshchestva. Vol.76. P.131-140. [in Russian].

Benediktov A.A. 2010. [New and interesting localities of orthopteroid insects (Orthoptera) from Russia and Uzbekistan] // Trudy Stavropolskogo otdeleniya Russkogo Entomol. obshchestva. Vol.6. Stavropol: "AGRUS". P. 35-37 [in Russian].

Childebayev M.K., Nurzhanov A.A., Medetov M.Zh. 2011. [Orthopterans Insects (Insecta: Orthoptera) in agrocenoses Karakalpakstan (Uzbekistan)] // Issledovaniya, rezul'taty. No.1. Almaty: "Agrouniversitet". P.11-17 [in Russian].
Lehr P.A., Ghahari H., Ostovan H. 2007. A contribution to the robber flies of subfamilies Stenopogoninae and Asilinae (Diptera: Asilidae) from Iran // Far East. entomol. Vol.173. P.1-14.

Podgornaja L.I. 1983. [Orthopteran insects of family Tetrigidae (Orthoptera) of the fauna USSR] // Trudy Zool. Inst. AN SSSR. Vol.112. P.1-95. [in Russian].

Sergeev M.G. 1982. [New localities of Orthoptera in Siberia and their possible zoogeographical importance. Note 1] // Poleznye i vrednye nasekomye Sibiri. Novosibirsk. P.42-46 [in Russian]. Storozhenko S.Yu., Ichikawa A., Uchida M. 1994. Review of Orthoptera of the Eastern Palearctica: Genus Tetrix Latreille (Tetrigidae, Tetriginae). Part 2 // New Entomol. Vol.43. Nos3-4. P.43-54. 


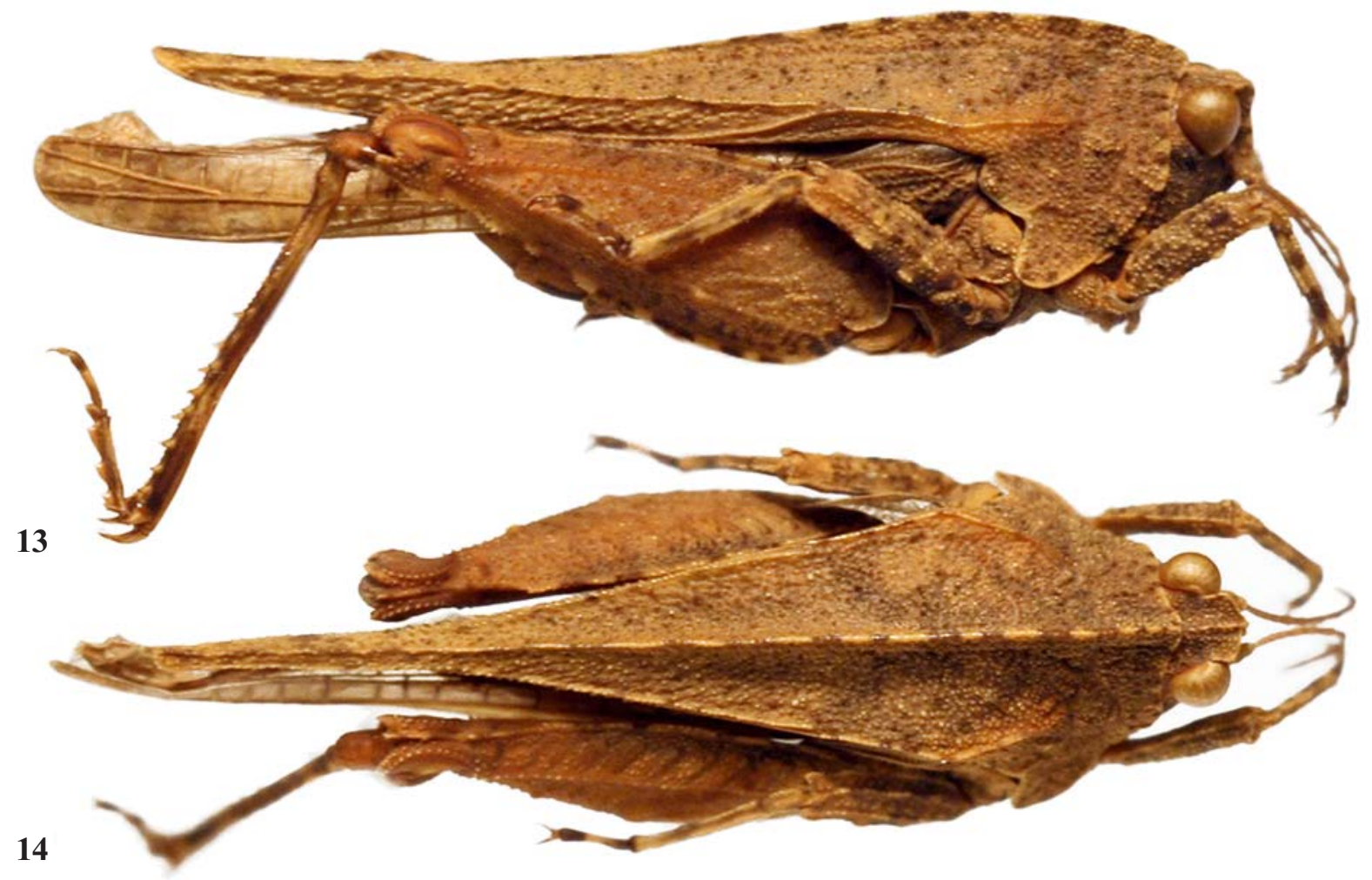

Figs 13-14. General view of Tetrix tartara subacuta f. macroptera from Baskunchak (Russia), ơ': 13 — lateral view, 14 — dorsal view. Foto: A.Benediktov.

Рис. 13-14. Внешний вид Tetrix tartara subacuta B.-Bienko f. macroptera из окрестностей Баскунчака (Россия), о ; 13 - сбоку, $14-$ сверху. Фото: А.Бенедиктов. 